Trinity University

Digital Commons @ Trinity

Classical Studies Faculty Research

Classical Studies Department

9-2014

\title{
Women After War: Weaving Nostos in Homeric Epic and in the Twenty-First Century
}

Corinne Ondine Pache

Trinity University, cpache@trinity.edu

Follow this and additional works at: https://digitalcommons.trinity.edu/class_faculty

Part of the Classics Commons

\section{Repository Citation}

Pache, C. (2014). Women after war: Weaving nostos in Homeric epic and in the twenty-first century. In P. Meineck \& D. Konstan (Vol. Eds.), The new Antiquity. Combat trauma and the ancient Greeks (pp. 67-85). Palgrave Macmillan.

This Contribution to Book is brought to you for free and open access by the Classical Studies Department at Digital Commons @ Trinity. It has been accepted for inclusion in Classical Studies Faculty Research by an authorized administrator of Digital Commons @ Trinity. For more information, please contact jcostanz@trinity.edu. 
CHA P T E R T H R E E

\title{
Women after War: Weaving Nostos in Homeric Epic and in the Twenty-First Century
}

\author{
Corinne Pache
}

While women play a circumscribed rolc in ancient epic, Homer's (Odyssey depicts both Helen and Pcnelope as undergoing their own forms of homecoming, or nostos, after the Trojan War: Helen returns to her husband Menelaus after experiencing the war firsthand at Troy and a ten-ycar separation; Penelope stays homc, but Odysseus' return is in many ways as much a challenge for her as it is for him and the Odyssey portrays her domcstic ordeal as a form of heroic nostos. In this cssay, I cxplore female ways of homecoming in the Odyssey and draw conncctions between Homeric hcroines and members of "Tcam Lioncss" returning home from Afghanistan and Iraq in the twenty-first century. 'T'he 2008 documentary Lioness gives voicc to some of these women, the country's first generation of femalc combat veterans, as they struggle to rcconcile their experience of war in Iraq with their lives at homc. While the ancient Greeks could not have conceived of women expcricncing battle in the way the mombers of Team Lioness did, Helen's and Pcnclope's marginalized roles in the Odysse $y$ open a window into the contemporary experience of women

soldiers and veterans and provide ways of understanding the challenges of the trauma of war and femalc homccoming in the twenty-first ccntury.

A central theme of the I-Iomcric Odyssey is the connection betwecn memory and idcntity. In the aftermath of the ten-ycar Trojan War, all the Greck heroes struggle to find their way back homc, but Odysseus famously undergocs the most difficult-and the longest- of the homecomings, taking ten ycars to return to his family on the island of Ithaca. Odysseus' journey culminates in his rcunion with his wife, Penelope, who tests his identity by appealing to their common memories of their marriage bed, a physical object that symbolizes the stability of their relationship. Whilc Penclope stays home and does not experience war firsthand, she is presented as undcrgoing somc of the same challenges at home as Odysseus experiences abroad, and through her husband's absence and 
return, Pcnclope in fact experiences her own mostos, culminating in the restoration of her home and marriage.

A striking Homcric image links the modern warriors in Ramadi and Penelope at home:

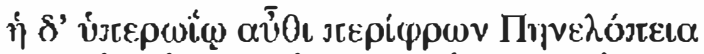

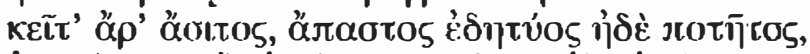

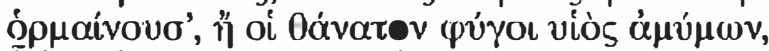

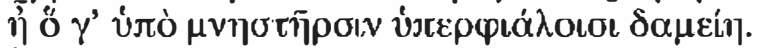

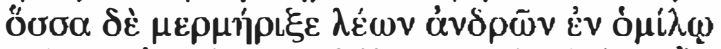

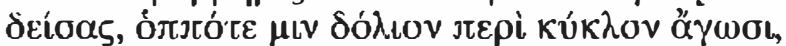

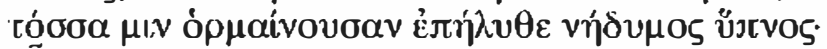

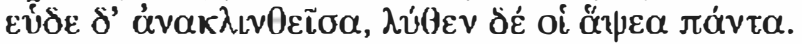

(Odyssey 4.787-794)

But she in the upper chamber, circumspect Penelope,

lay therc fasting, shc had tasted no food nor drink, only pondcring whether her stately son would escape from dying or have to go down under the hands of the insolent suitors; and as much as a lion caught in a crowd of men turns about in fcar, when they have made a treacherous circle about him, so she was pondering, when the painless sleep came upon her and all her joints were relaxed so that she slept there reclining. ${ }^{2}$

Lion similes in Homeric poetry typically depict warriors in combat situations, and so the connection between Pcnclope and a trapped predator at first seems tenuous. 'The fearfill beast of the similc is ostcnsibly in great danger, but the animal's plight is left unresolved as Pcnclope falls asleep. The lion simile at the cnd of Book 4 is the second lion simile in that book, and in the pocm, following upon the first extended simile in the Odysse $\gamma$, a fow hundred lines carlicr, where Menelaus imagines Odysseus' cventual return homc as a lion attacking a doe and the fawns she has brought to the lion's lair $(4.332-340=17.124-131)$. When the narrator comparcs Penclope to a lion later in Book 4, the audience inust recall Menelaus' description and thus the leonine Odysseus and Pcnclope arc placed in a dialogue with each other. ${ }^{3}$ Odysseus is in addition compared to a lion in five other similes, culminating in the similc of Book 22, which describes his nurse, Eurycleia, finding him covcred in blood, standing among the suitors like a lion, "a tcrrible thing to look in the face," a simile that is then repeated by Eurycleia when she in turn describes the same scene to Pcnelope at the bcginning of Book $23 .^{4}$

It is significant that Penelope is compared to a lion in a pocm that is framcd by two similes describing Odysscus' vengcance as that of a lion. Lionesscs, real or imagined, are also predators, who, whon they become surrounded by hunters, kill to save themsclves and thcir young. When 
Homeric lions facc a human opponent, moreover, they almost always prevail. Penelope may resemblc a lion, but never finds herself in a position where she has to do the fighting. While Pcnclope does not expcricncc combat, through the lion simile she is associated with Odysseus' brutal slaughter of the suitors and by extension with the many Iliadic lion similes depicting men in combat. The lion simile thus gives us an ancicnt Lioncss, a woman thrust into the "trcachcrous circle" of battle.

The lion simile has another important counterpart in the Iliad, where Achilles, strikingly, mourns Patroclus like a lion who has lost its cubs (18.316-322), an image that we also find in the earlier Epic of Gilyamesh, where the hero mourns the death of his fricnd Enkidu, "like a lioness whose cubs are in a pitfall."5 Another Iliadic simile describes Ajax protecting the body of Patroclus as a maternal lion: ${ }^{6}$

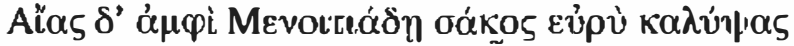

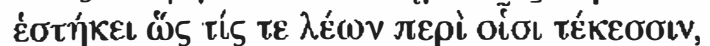

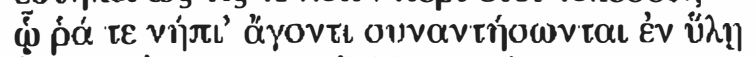

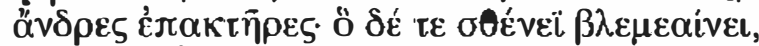

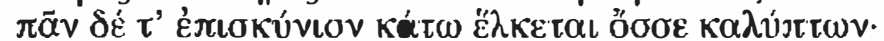

(Iliad 17.132-137)

Now Aias covering the son of Menoitios under his broad shield stood fast, like a lion over his young, when the lion is leading his little ones along, and men who are hunting come upon them in the forest. He stands in the pride of his great strength

hooding his eyes under the cover of down-drawn eyclids.

While the Homeric lions are grammatically male, they seem to sharc the maternal inclinations of the mother lioness in the Epic of Gilyamesh. In all these examples, lions (and lioness) are always depictcd in the act of attempting to protect, or lamenting, their own blood rclatives, most cspecially their own children. ${ }^{7}$

Homeric lions often appear on the battlefield via similes, but strikingly, as we have just secn, they often figure as maternal animals trying to protect their offspring or mourning their loss. Homeric warriors are thus imagined as mothers to one another. ${ }^{8}$ The lion is also a symbol of vengeance and of the predator's proverbial supcriority over its human and animal rivals. The implications of the Iliadic simile comparing mourning Achilles to a lion are clcar: nothing is more dangerous than a mourning lion keen on revengc.

At the moment she is comparcd to a lion in Odyssey 4, Penelope is also in a state of mourning for her presumably lost husband and absent son. Iion similes thus evoke both war and its consequences by suggcsting a kind of rnouming that gives rise to wrath and desire for revenge. Penelope the lioness does not experience battle, yet Homer's comparison 
strikingly suggests just this possibility, in an image that is all the more surprising given the attitudes of ancient Greeks toward fighting women. (As an aside, the Greeks did not seem to be aware that among real lions, it is in fact the lioncss who docs the hunting, while the males are, as it were, the homebodies.)

While women do not experience battlc firsthand in Homcric cpic, war affects them in many ways, including thcir social position. Def ined by thcir marital status in cveryday life, women become prizes during conflict, and wives risk bccoming slaves. Helen, a stolen wife, is the cause of the 'Trojan War and is central to the conflict, cven as she stands by as an obscrver. She finds hersclf bricfly on the losing side when the Grceks sack Troy, but is ultimatcly rcunited with her husband Menelaus, instead of enslaved by the Grcek victors, which is the fate of the 'l'rojan women. For Penclope, war and her husband's long absence have also put her in a dceply ambiguous situation: she is neither wife nor widow, thus attractive as a potential bride yet unable - and certainly unwilling - to rcmarry. The end of the Trojan War restores both Helen's and Penelope's identities as marricd women, but both figures remain ambiguous because of their potential for independencc. Whilc modern attitudes toward women in war arc fundamentally different, the Homeric image of Penelope the lion and the struggles of the Honieric heroincs can be connccted to thosc faced by the women of Team Lioness, the first gencration of US women sent into direct ground combat in Iraq (Figure 3.1).

Bccausc it is unacceptable in Iraqi culture for male soldiers to interact with women, in late 2003 US Army commanders started to attach tcams of female support soldicrs to battalions of Marines to interview and search Iraci women during scarch missions. Lioness, directed by Meg McLagan and Daria Sommers, tells the story of five fomalc soldicrs: Shannon Morgan, Rebecca Nava, Kate Guttormscn, Ranic Ruthig, and Anastasia Breslow. 'Through the women's own words (in convcrsations and cxcerpts from thcir diarics), archival footage, and newsreel, the filmmakers explore the women's homecoming and include flashbacks to combat the women faced in Ramadi in the spring of 2004.

In this documcntary, Coloncl William Brinklcy is credited with establishing and naming the first Lioncss Tcam (Figurc 3.2). While the name "Shield Maidens," which evokes Scandinavian myth, was apparently considered, Brinkley settled on the animal moniker. Whether he was thinking of predatory or literary connotations is not known, but the comparison of women to lions - whether ancient or modern-is evocative of victory, vengcancc, and mourning after battle.

While the film is a straightforward documentary, it threads images of prey and predator throughout its narrative. The first image is a shot of a fawn looking directly into the camcra, beforc turning and running away in fcar. On one level, the fawn sets the scene in the countryside of Mcna, Arkansas, where the first section of the film, focusing on Shannon Morgan, takes place. But docs the fawn stand in for the lioness or for her 


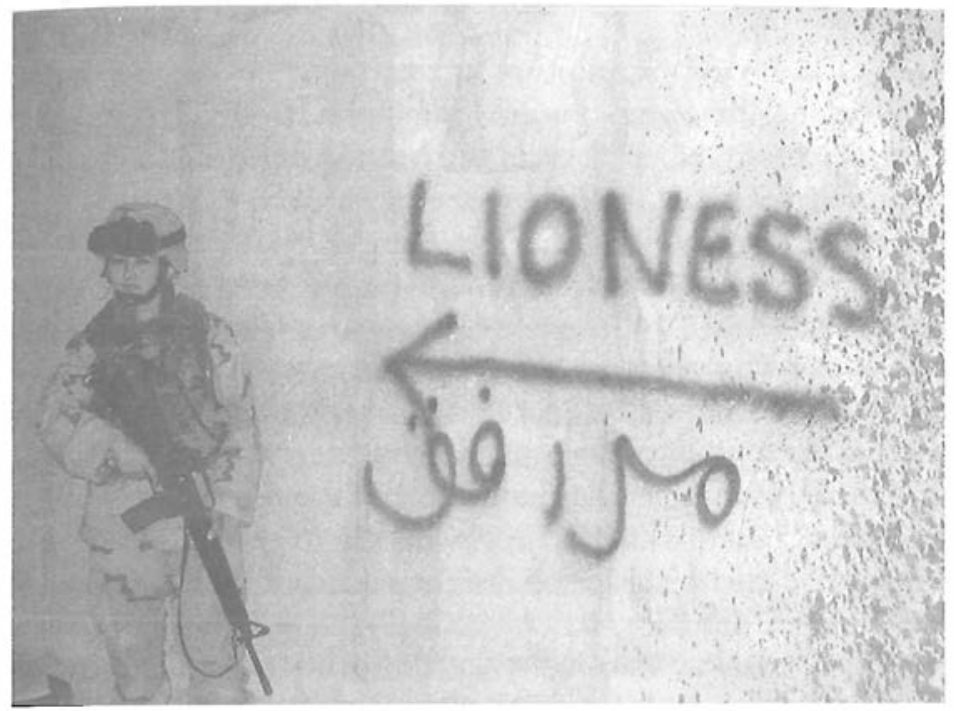

Figure 3.1 Scrgeant Michelle Brookfield Wilmot on guard duty in Ramadi, lrag in April 2005 Plocograplo hy Spe. Mirrandia Matcisugly.

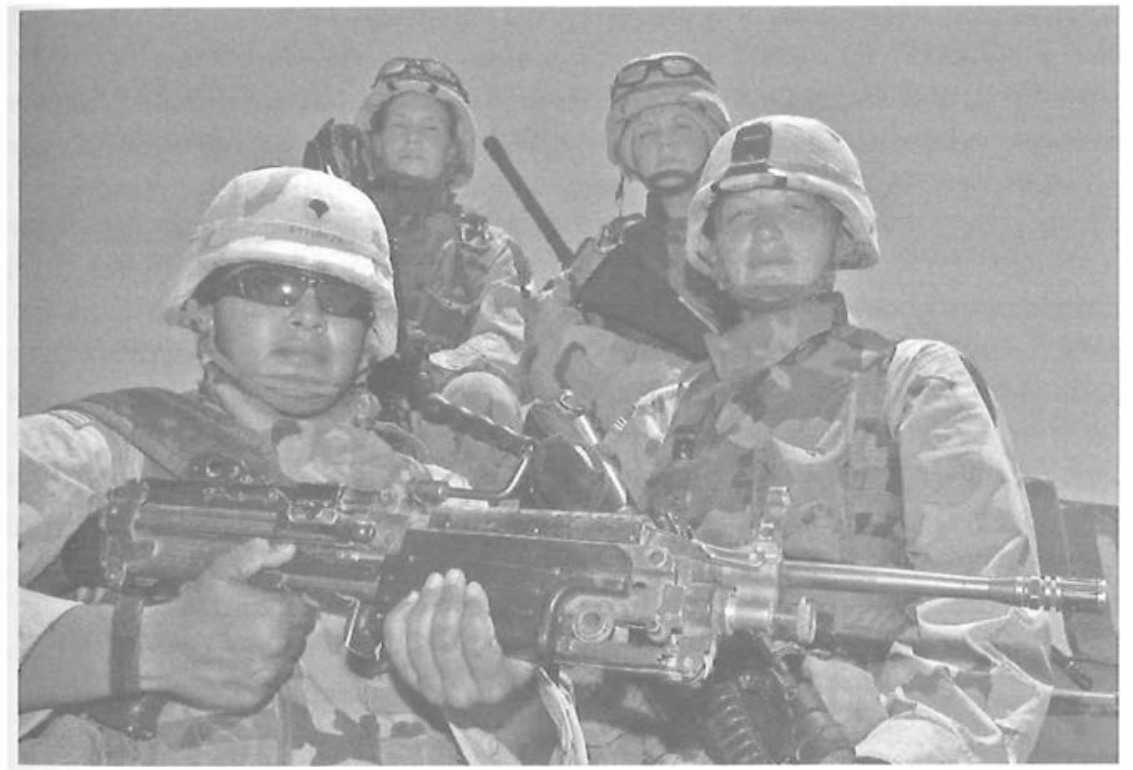

Figure 3.2 Lionesses Cynt hia Espinoza, Ranic Rulhig, Shamnon Morgan, and Michelle P'crry in Ramadi, iraq in July 2004.

Plotograph by Lloyd Fraticis, Jr. 
prey? Shannon at home is a hunter, but also somcone who remembers being luunted.

In spite of the legal prohibition against women on the battlefteld in effect at the time, the members of Team Lioness often found themselves in combat situations when they accompanied male soldiers during raids to find hidden weapons in the houses of suspected insurgents. Captain Manning, director of the Women in the Military Project based at the Women's Research and Education Institute, observes in the film that the Lionesses were forced to violate the policy in place at the time in order to do the jobs assigned to them. The Lionesses had no official status, and their actions were not documented, since the US Army could not acknowledge the presence of women in combat situations. The role played by the Lionesses in Iray and Afghanistan and the difficulties they encountered on their return must have played an important role in Defense Secretary Leon Panetta's decision (at the unanimous recommendation of the Joint Chiefs of Staff) to overturn the ban on women in battle in the US military, a welcome corrective to the earlicr practice, which resulted in a lack of recognition of the women's actions and unfair discrimination, especially for returning female veterans in need of treatment for physical or psychological injuries experienced during combat."'

Ordering untrained female soldiers into situations that could involve battle came with its own set of dreadful dilemmas: Army support soldiers are, by definition, not trained for combat, making hazardous situntions even more dangerous; moreover, the Lioness team was composed of female Army soldiers who were sent to the battlefield with Marines, who function according to different rules and often speak what amounts to a different language.

Specialist Shannon Morgan, a mechanic, describes the shock of her first experience of accompanying a firing team of Marines during raids against insurgents. Because Shannon has the skills to fire a squad automatic weapon (SAW), the Marines wanted her to cover their rear. As they made their way through the city, the firing team came under attack, and Shannon, for the first time in her lifc, found herself in a combat situation. As bullets flew by, Shannon noticed one of the other Lionesses, Staff Sergeant Ranie Ruthig, also a mechanic, signaling to her from the top of a nearby building:

And all of the sudden I looked, and everybody was gone. I was the only one in the strcet, there were insurgents all around me, firing at me. I'm like son-of-a-bitch! You know? I didn't know what to do... Ranic's like-going like this, like, trying to get my attention, "get over here," or something, "run." Because in Army, you tap back. You tap every man back and you let them know you're moving. These bastards didn't say nothing to me, just left me there. So I ran for my damn life and caught back up with my firing team-when I 
got there I kicked the squad leader right in the nuts for leaving me. I surc did. (Lioness, chapter 10, at 40:03)

The Lionesses lacked not only the training necessary for combat, but also the very language to communicate effectively with the Marines to whom they were assigned. While Shannon was doing the job assigned to her according to the training she received, communication failure causes her to be left behind in mortal danger.

Communication plays a central role in the Lioncsses' experience of war and subsequently in their homecoming, when finding ways to tcll their story brings the women somc solace. While soldiers returning from war in the twenty-first century have a varicty of media at their disposal from diaries to film, in Homcric cpic, women use weaving to tell their experience. Women and men occupy different rcalms in Homer, and women's place is by their looms, as Telemachus reminds Penelope when he asks her to go back to her loom whilc the men focus on talk and the contest of the bow that determines Penelope's fatc (1.356-359 and 21.350-353). Weaving is singled out as a female activity, but it is also the means through which women are able to tell their story." Whilc Teletnachus contrasts the loom with the power (kratos, 21.353) invested in the malc head of the houschold, it is striking that the narrative of the Odyssey subtly undercuts his attempt to keep male and female realms scparatc by using the same word, polstpcuo ("to complctc," "to bring to an end"), to describe Penelope's wcaving and Odysseus' completion of the war, thereby suggesting that Penelope is both essential to, and participates in, her husband's successful hornecorning. ${ }^{12}$ In both the Iliad and the Odyssey, both Helen and Penelope are portraycd as master weavers whose weaving encapsulates the different ways in which they react to the war and its aftermath.

In the Iliad, Hclcn wcaves what she sees:

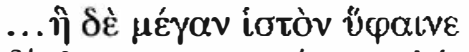

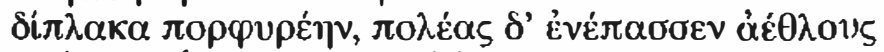

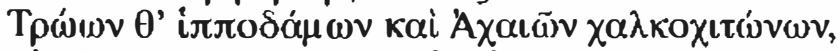

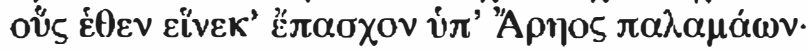

(Ilind 3.125-128)

...she was weaving a great web,

a red folding robe, and working into it the numcrous struggles of Trojans, breakers of horses, and bronze-armored Achaians, struggles that they endured for her sake at the hands of the war god.

This arresting image of Helen at the loom presents her as both causc and observer of the war. Helcn's visual narrative encompasses not only the sufferings and the great deeds of the Grcek horocs, but the "struggles" of both sides, mirroring the Iliad itself and its insistcnce on depicting 
war as devastating to both victors and loscrs. Helen bears witness to the carnage she has caused and is observing fiom a distance but she remains sccmingly unaffected by the events she watches. While Helen bccomes a poct of sorts, her web is full of paradoxes: her storytelling is so private that it is addressed to no audicnce but herself; and while she depicts events that she notionally causcd, shc is noticeably absent from the scene she creates.

Pcnclopc, by contrast, uses weaving to control events as she faces the consequences of the war and her husband's long absence. At home in Ithaca, Pcnclope sces nothing of the slaughter on the Trojan plains. Neverthcless, the war and its aftermath are for her a source of constant gricf. Shc cannot bear, for example, to hear the singer Phemius sing "of the Achaians' bitter homccoming /from Troy, which Pallas Athene had inflicted upon them" (Hom. Od. 1.326-327). Lattimore's choice of the adjcctive "bitter" to describe the Achaians' homecoming captures the double-edged nature of the Greek liggron, "bancful, mournful." The nostoi of the Achaians are bitter for them to expericnce, but also bitter for others to remcmber, and to Penelope, they bring "unforgettable sorrow" (1.342). Telling the suitors that she will remarry only when she has completed the burial shroud for her (still living) father-in-law, Penelope uses weaving - and unwcaving - to deal with the consequences of the Trojan War in Ithaca. Unlike Helen, Penelope shows no intercst in recording the events that surround her, and has no wish to momorialize her suitors' sordid feasts, but her wcaving, likc Helen's, is also a way to tell her story and shape her futurc momorics. By unweaving at night what she wove in the daytime, she is able to postponc giving an answer to the suitors who want to marry her and thereby gain a measure of control over her own fatc. Pcnelope's weaving is a symbol of her cunning, but also her way of controlling the narrative of her life. ${ }^{13}$ Helen's and Penelope's weaving thus stresses two important problems for women who face war and its consequences: how to tcll a story for which there is no audience; and how to control and tcll the story that has not yet been written.

For the members of Tcam Lioness, the ambiguity of their mission-to give support in combat situations that they, strictly speaking, arc not expected to be in-marks both their expericnce in war and their homecoming. The ambiguity of their position is reminiscent of Penelope's ambiguous social position in Ithaca during Odysseus' absence, when she is both a wife and not a wife. For Penelope, it is cssential to maintain her ambiguous status so she can control events, delay an cvcntual remarriage, and wait for Odysseus. For the Lionesses, the ambiguous nature of their position protects the mon who order them in battle while it creates problems for the women when thcy come home. How does one come back from, and come to terms with, an expcricnce that is not supposed to have happencd at all? How can the former Lioncsses find ways of telling their stories, which for many of them are too painful to be told? Because of 
what Captain Lory Manning describes as "the big disconnect right now between what the policy says women can do and what women are doing," the members of Team Lioness faced further hardships when they returned bome to a society that did not recognize what they experienced. The film gives the Lionesses a voice, but there was no official mechanism to help these women gain access to professional recognition for their actions or to the treatment they might nced. This of course has many harmful consequences for both their professional and personal lives.

In Homeric cpic, warriors are compcnsated for their sufferings in wâr by becoming immortalized in poctry. Women suffer in, and as a consequence of, war, but thcy remain marginal characters in epic. While the Iliad stops short of describing the sack of Troy, the Odyssey explores the fomalc experience of war in a famous simile in Book 8, describing Odysscus' reaction to the song just sung by the Phaiakian singer Demodocus. Demodocus' song glorifies the Greek victory at Troy, but Odysseus surprisingly breaks down when he hears the singer's praise of his own endurance in battle:

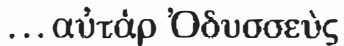

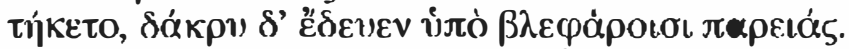

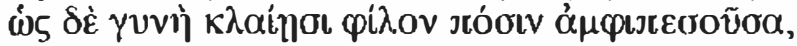

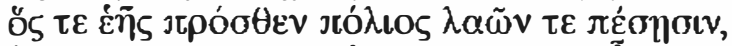

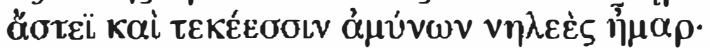

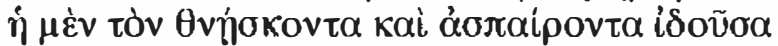

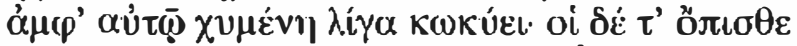

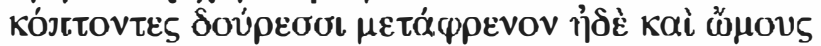

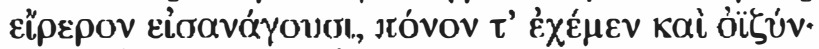

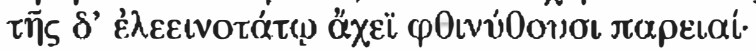

(Odyssey 8.521-530)

...but Odysscus

melted, and from under his eyes the tears ran down, drenching his checks. As a woman weeps, lying over the body of her dear husband, who fell fighting for her city and pcoplc as he tried to beat off the pitiless day from city and children; she sees him dying and gasping for breath, and winding her body about him she cries high and shrill, while the men behind her, hitting her with their spear butts on the back and the shoulders, force her up and lead her away into slavery, to have hard work and sorrow, and her cheeks are wracked with pitiful wecping.

Listening to Demodocus' song, Odysscus crics for himself, his lost companions, and for the violence and suffering he has experienced in the past 20 years. Whilc the passage describes a martial victory, the poct of the dyssey offers a tragic scene that focuses on the human costs of war. 
The song also evokes a spccific event in the Trojan War, to which I wi return below. The woman in the simile is a victim of war-the Troja Princess Andromache, Hector's widow, immediately comes to mindand Odysseus is also in some sense crying for her and the violence and suffering he has caused. This is a crucial moment in the Odysscy, in which the victor is described as seeing the war from the point of view of the most vulnerable of his victims.

Yet it is also striking that the woman to whom Odysseus is comparcd is nameless: the anonymous woman who embraces her dying husband, and who, like the women on the losing side of the Trojan War, loses everything, including her identity. The passage in fact functions as an identity marker for Odysseus: his role during the sack of Troy signals him as a war hero, but his tears also liken him to a combat victim, and shortly after his breakdown Odysscus finally reveals his name and identity to his hosts. But while the passage cstablishes Odysscus as a hero, the ancicnt poct also stresses throughout the Iliad and the Odyssey that war-and the memory of war-always conjures loss and hence tears for the men involved (sce chapter 2 in this volume).

The Homeric poems include many descriptions of wecping warriors, in a stark contrast with the gendered meaning ascribed to tears in modern US military culture. ${ }^{14}$ Kate Guttormsen, the only female company commander at Ramadi who came to be in charge of choosing the women sent on I.ioness missions, confesses that she thinks women soldiers are better equipped to deal with strong emotions than men because they are loss afraid to express them:

I don't think my experiences werc any different than my male counterparts. I think some of my coping mechanisms werc different. For examplc, I'm surc I cried more than my malc counterparts-bchind closed doors. $^{15}$

For Guttormsen, as for Odysseus and Achilles, tcars arc a natural reaction to somc of the cvents she witnessed. I will return below to what she calls clscwhere "the emotional side" of war and the ways in which it affects femalc soldiers.

In Homeric epic, women experience war from a distance. Helen is the only woman to come back from Troy, but in contrast to the heroes whose homecoming becomes the subject of song, she returns to a world in which remembering her actions in Troy is a source not of storytelling and epic klcos ("fame") but of grief. When Telemachus visits Sparta to gather information about his father in Odyssey 4, he finds Menelaus and Helen living in extraordinary luxury, but the beauty of their palace and its furnishing cannot hide the lack of harmony betwecn the spouses. Their conflicting memories of the war are so painful that they can only reminiscc about the past after taking a pharmakos, a drug in Helcn's possession that counteracts grief. 
After Hclen and her husband partake of the phammakos, both remember episodes from the war that draw attention to less heroic moments away from the battlefield. Helen tells how she recognized Odysseus when he made a foray into the city disguised as a bcggar. Whilc Helen remembers trying to help the Grceks, Mcnelaus counters with his memorics of her trying to trick the Greck warriors out of the Trojan horse by imitating their wives' voices, tempting them to forget war for wives, and inspiring them with a yearning for home so powerful that it almost causes them to abandon their mission at the most dangerous moment possible. But ultimately, Menelaus' story is about Odysscus' power of restraining the other men hidden in the horse and Helen's motivations remain mysterious.

The difficultics faced by Hclen when remembering her role at 'Troy are mirrored in the modern Lionesses' troubles in remembering and telling their storics." Because memories are intricately linked with identity, telling one's story is an important way of recovering from trauma. Yet traumatic memories are difficult to narrate preciscly becausc they are dominated by nonverbal components such as sounds, sights, and emotions that are difficult to translate into a connected narrative. T'raumatic memories can further causc individuals to lose a sense of the coherence of their entirc life narratives, and lead to confused memorics, as in the case of Helen and Menelaus, or to memories that are impossiblc to put into words. ${ }^{17}$

Trying to communicate what she has been through to her parents, Shannon finds it difficult to find words (Figure 3.3): "I didn't really know

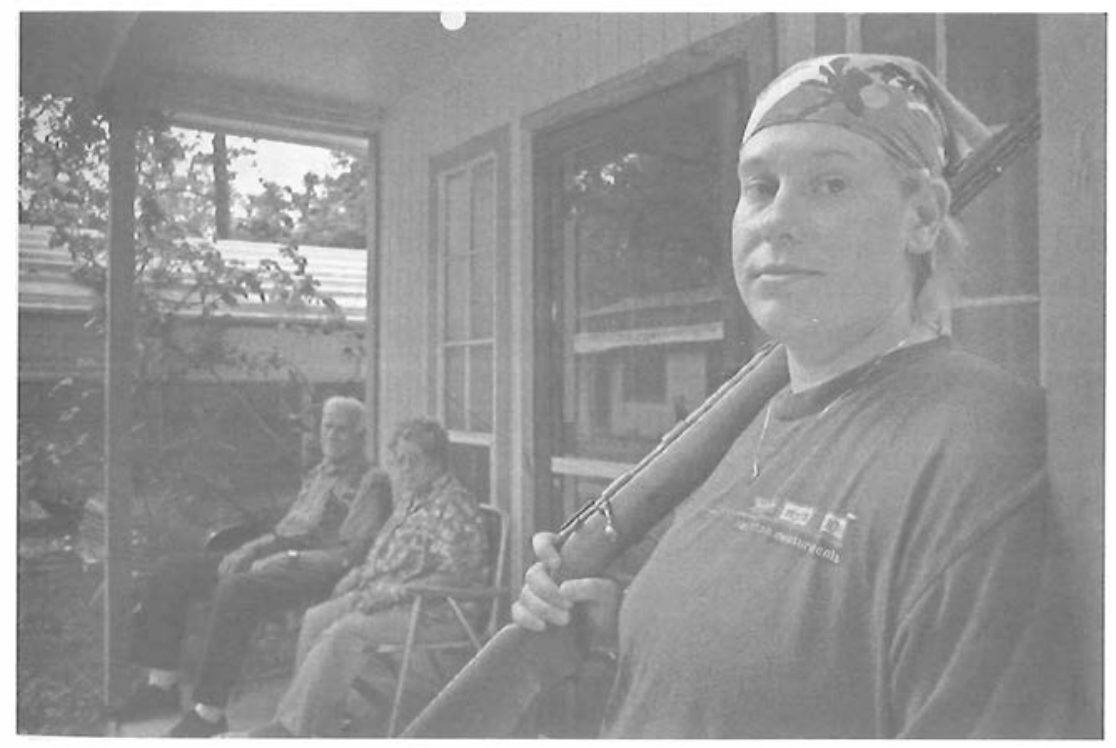

Figure 3.3 Shamon Morgan ou her parems' porch is Mera. Arkansas.

Plocograph by Stepliczz T. Mairaz: 
what to say." She finds some solace with her uncle, a veteran from the Vietnam War, as they sit together, "not saying a word," yet understanding one another becausc of their common experience in war. The Lionesses find it not only difficult to recount their experiences after they return, but also at the timc because they did not wish to be a source of worry for their families. Shannon explains how even when she had the opportunity to tell her mother on the phone what she was doing in Ramadi, she could not tell her because she feared her mother would be so worried that it might affect her health. For Ranie Ruthig, her inability to manage het memorics after her return results in bursts of uncontrollable anger typical of PTSD that lcave her feeling both psychologically exhausted and full of guilt toward her family, cspecially her young daughter. ${ }^{18}$ Ranie finds it particularly difficult to transition from her role as soldier to her role as mother.

When Helen and Menelaus talk of their memories at Troy, they both in different ways stress the notion of war as transgression. The rolc played by Odysseus and the other (jrecks is ambivalent at best: thcy lurk, hide, and trick the Trojans into utter defeat, but the Greeks' victory is marred by its deceptive nature. Let me return to the song sung by Demodocus that provokes Odysseus' tears in Odyss' $y$ 8:

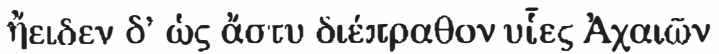

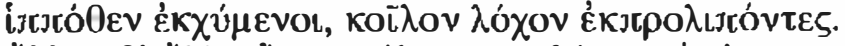

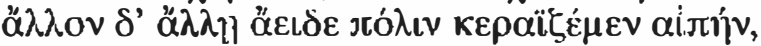

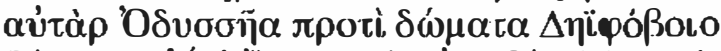

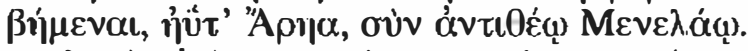

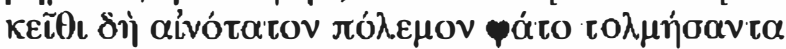

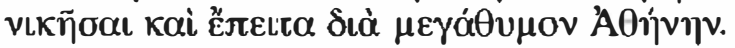

(Odyssey 8.514-520)

Hc sang how the sons of the Achaians left their hollow hiding place and streamed from the horse and sacked the city, and he sang how one and another fought through the steep citadel, and how in particular Odysseus, went, with godlike

Menelaus, like Arcs, to find the house of Deiphobus, and there, he said, he cndured the grimmest fighting that ever he had, but won it there too, with great-hearted Athene aiding.

At Odysscus' request, Demodocus sings of the wooden horse and the destruction of Troy. I have already discussed Odysscus' reaction to the song and the comparison of the hero to a captive woman, but his reaction is cven morc surprising given that the trick of the Trojan horse, and hence the sack of 'Iroy, is celebrated as Odysseus' grcatest victory. Yet taken together, Demodocus' song and Odysscus' tears offer a compressed 
version of the war and of the typical Homeric way of remembering war, which always acknowledges the indissoluble connection between battle and lament. Consider the Ilisad, with its celebration of martial deeds that always lead to moursing, which becomes increasingly prevalent in the later parts of the poem. Achilles, accompanied by his mother and the Nereids, mourns the loss of Patroclus in Book 18, while the Trojans lament Hector in Book 22. Mourning takes center stage in Book 2.3 with the funeral of Patroclus and culminates with the tears of sorrow shared by Achilles and Priam in Book 24. Victors and losers mourn alike in the lliad, and not even Zeus is immune to the grief brought upon by war, reacting to the death of his son Sarpedon with tears of blood (16.459).

Odysseus' tears in Odysscy 8 are also connected to the specific cvents, "the grimmest fighting" he ever endured, which took place at Dciphobus' house during the night of the sack of Troy. Demodocus does not give any details about what Odysseus did there, but the ancient audience would have known Deiphobus as the Trojan prince whom Helen marries after the death of Paris. When Menelaus and Odysscus go to Deiphobus' house, it is for one very specific reason: to get Helen back. And Helen plays a central role in what happens therc.

To get a glimpse of that "grimmest" of battle, we have to turn to Vergil's Acneid 6, wherc Aeneas encounters the dead Deiphobus in the underworld and hears the Trojan's version of the same events: Deiphobus recounts how Helen betrayed the city, leading the Trojan women into an ecstatic dance whilc simultancously signaling to the Greeks to come out of their hiding placc. While Deiphobus is asleep. Helen prepares for the Greeks' arrival by removing all weapons from his house. She then summons Menelaus and Ulysses inside, and they brutally mutilate and kill Deiphobus. The Roman Vergil to be sure presents a perspective that is as anti-Greck as possible-his Helen helps Menelaus and Ulysses to torture and slaughter her defenseless Trojan husband. When carlier in Book 2 Aeneas describes his own encounter with Helen during the sack of Troy, he portrays her as a dreadfill presence, crouching in the shadows of Vesta's shrine, in fear of both the Trojans' and the Greeks' wrath. Aeneas is enraged at the sight of the hated woman whom he describes as the "Erinys," the vengeful curse bringing destruction both her own country and his own (2.57.3).

While the Odyssey does not describe the scene in the house of Deiphobus in any detail, the word Demodocus uses to describe the fighting is ainotaton, "the grimmest" or "the most dreadful," a word that connotes a transgression of some kind. Odysseus uses the same word to warn his companions of the "most dreadful evil" (ainotaton kakon) that awaits them on the island of Helios, where his companions will find death after they consume the forbidden cattle of the sun god (12.271-276). Yet the Odysscy 
remains silcnt on the events that take place at the house of Deiphobus, during the battle to recover Helen, which is in some sense at the center of the narrative of the Trojan War. And Helen at Sparta is depicted as a potential traitor whose past actions are so painful that they can only bc remembered by her and her husband when they are drugged. Whatever the reasons for Demodocus' reluctance to mention Helen-whether he is unwilling to mention her second Trojan marriage or loath to ascribc any part of Odysseus' success in a war to a woman's help-we are left with a flickering and tantalizingly inconsistent image of Helen at Troy and at home: was she there at all or did she remain in Egypt, as Euripides has her do in his Helen, whilc the Greeks pursuc her ghostly image to Troy? Is she always the enemy?

Helen's disappearing act finds its counterpart in some contemporary documentaries telling the story of the Iraq War. In Lioness, we witncss a reunion of the team during which they watch together "Battlecry Iraq: Ramadi," an episode from the History Channcl's scrics Shooloul, which focuses on reconstructing famous historical battles. "Battlecry Iraq: Ramadi" depicts the struggles faced by US Marincs in the spring of 2004 as they faced insurgents on the streets of Ramadi, including the same battle in which the I.ioness teams were involved and which they recount in the central section of Lioness. ${ }^{19}$ Although both films center on the same events, the contrast between the two versions could not be more striking. "Battlecry Iraq" of course belongs to a subgenre of war documentary that filters historical events through a traditional vicw of battlc as the business of men: "witness real life-and-death combat, housc-to-house, block by block, told for the first time, by the men who were there," announces the narrator at the beginning of the documentary. But while the documentary details the skirmishes between Americans and Iraqis in Ramadi and purports to tell of real cvents, using archival footage and intervicws, it has no place for the untraditional Lionesses who were, in fact, there, and simply clides their presence. Womcn - whether American or Iraqi for that matterare completely absent from the narrative. The omissions of "Battlecry Iraq" contribute to the documentary's generic and unproblematic vision of war, which has nothing to of fer to the Lionesses who are still struggling to come to terms with their experiences in Iraq. Like Helcn who comes home from a city at war only to find her experience muted through the pharmakos, or Penelope, whose role as narrator is severely curtailed in the Odyssey after dysseus comes home and retakes control of the household (and the story), the women of Team Lioness comc back from Iraq to find that their experience is neither acknowledged nor remembered. ${ }^{20}$

While some of the bluster is typical of the Shootout! series, the men also tell their stories in their own words, which reflect their different training and reactions in the face of combat. A soldicr describes discovering 
an insurgent's silhouette against a lighted background as "a dream come true" because he could easily aim at and kill his target. Lioness by contrast brings to the forefiont the moral dilemmas faced by soldicrs and the ainotaton, the "grimmest," dimension of war. As they break into the houses of presumed insurgents to scck hidden weapons and information, the Lioncsses have to trust that they are acting on trustworthy information. Ranie Ruthig imagines what it would be like to be at the other end of the search missions, which mostly took place between $11 \mathrm{p} . \mathrm{m}$. and 5 a.m.: "I felt like the Gestapo. You know, all I could think of was what would I do if they did this to me?" Similarly, Anastasia Breslow writes in her diary that she finds the search missions unsettling: she imagines how she herself might react: "If someonc rammed my gatc down in the middle of the night I might be inclined to plot. We just have to have faith in the intel that these pcoplc arc doing wrong."

Upon her return, Shannon Morgan continues to strugglc with the implications of having killed another human being in the streets of Ramadi. She knows she had no choice and had to kill the man who was aiming at her before he shot her. She says that shc is happy to bc alive and to be back home, but also fecls like she lost a part of herself when she took a human life in Iraq. Katc Guttormsen quotes what she wrote in her diary the day on which Shannon Morgan killed the insurgent and remembers another officer's rcaction:

I cannot imagine the feelings that she [Shannon] must be experiencing. Gave her a huge hug and didn't say anything. Chief Warrant Officer at the time came up to me becausc he saw me give her a hug and he said, "Remcmber, you're in charge." Which really bothered me because there's still an emotional side, you know, which I found, while I was over in that environment, that the women deal with much better than men, you know? I tricd not to do it in front of people, but I would get teary-eyed when there wcre bad days, and I would break down when there was a bad day. I'd try to do it bchind closed doors but you can't always do that. (Lioness, chapter 10, at 49:56)

What comes through again and again in Lioness is the difficulty for the team members to talk about what they have becn through. Words are not enough: Kate Guttormsen "didn't say anything," while Shannon Morgan didn't know "what to say." Yet, while it may be impossiblc to find words adequate to recollect their painful experiences, the Lionesses are also keenly aware of the importance of telling their storics. "The film is framed by Shannon Morgan's emphatic statement, "you don't cver forget," which functions as both introduction and conclusion, and both an cxplanation and an imperative: Shannon cannot forget what happened to her, but neither should we. Where both "Battlecry Iraq: Ramadi" and Lioness and both male and female soldiers agrce-cven if they do it in different 
ways-is on the absolute nccessity to remember, and more particularly to remember fillen soldiers.

By way of conclusion, let me go back to the Odyssey, and its homebound leonine heroine. Although she never leaves her house, P'enelope is singled out by the ancient poet for both her struggle and her achievement. The epic kicos that is denied to unfuithful wives such as Helen (or (lytemnestra) instcad goes to Odysseus' steadfast companion. Just after their final reunion, Odysseus breaks down:

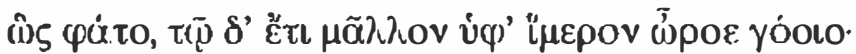

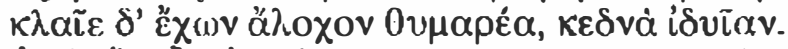

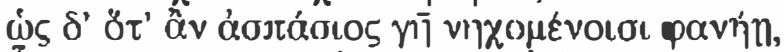

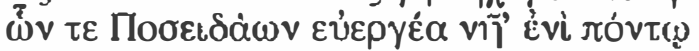

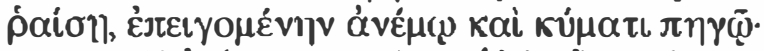

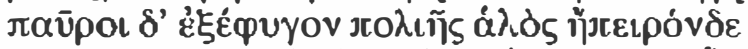

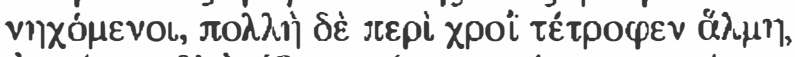

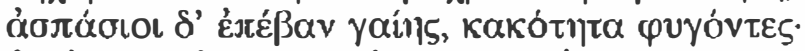
(i)

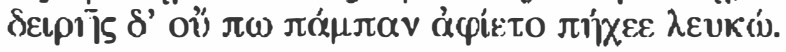

(Odysscy 23.2.31-241)

She spoke, and still more roused in him the passion for weeping.

He wept as he held his lovcly wife, whose thoughts were virtuous.

And as when the land appears welcome to men who are swimming, after P'oseidon has smashed their strong-built ship on the open water, pounding it with the weight of wind and the heavy seas, and only a few escape the gray water landward by swimming, with a thick scurf of salt coated upon them, and gladly they set foot on the shore, escaping the evil, so welcome was her husband to her as she looked upon him, and she could not let him go from the embrace of her white arms.

In the end, the Odyssey does grant Penelope her share of heroism. This powerful double simile, which suggests that men's and women's experiences can be reconciled, also stresses the ways in which nostos always remains an incomplete tapestry woven and unwoven by both those who leave and those who remain. Shuttling back and forth between modern and ancient expericnce, we weave new narratives of war and homecoming that include those who have been marginalized by ancient pocts and those who are neglected by contemporary institutions. While Homeric epic gives the "female racc" a circumscribed role, it also gives us a lioness heroine who is remembered as undergoing a heroic nostos of her own, and, in so doing, provides us with a model for contemporary and future homecomings. 


\section{Notes}

1. For a study of Homeric epir, and PTSD in the twentieth century, see Shay (1994, 2003). For the reception of Homer in the twemieth and tiventy-first centuries, see Graziosi and Greenwood (2010) and Hall (2008).

2. All translations of Homer are by Lattimore (1951, 1967).

3. See Heubeck et al. (1990, 243) for Stephanie West's summary of the sclıolarly reception of the simile. which she concludes is "inept;" for the ways in which the lion similes connect Penelope and Odysseus, see, for example, Moulton (1977, 123); see also Magrath (1982, 207), who notes that the poet highlights "Penelope as the passive mate for Odysseus as the active lion." I examine this simile in greater detail in a forthcoming article.

4. There are seven lion similes in the Adyssey (or five, if we discount repetitions): Odysseus the lion coming back to his lair, 4.333-340 = 17.124-131; Penelope the lion. 4.787-794; Odysseus compared to a lion during his encounter with Nausicaa, 6.127-137; Polyphemos eating Odysseus' men compared to a lion, 9.287-295; Odysseus after the slaughter of the suitors, $22.402=23.48$.

5. Tablet VIII.56-63. Translation by Foster (2001).

6. The comnection between lionesses and materinal love and vengeance is perlaps linked to the strange belief about real lionesses only giving birth to one cub recorded by Herodotus, Hisiorics 3.108.4: "On the one hand there is this sort of thing, but on the other hand the lioness, that is so powerf ul and so bold, once in her life bears one cub; lor in the act of bearing she casts her aterus out with her cub. The explanation of this is that when the cub first begins to stir in the mother. its claws, much sharper than those of any other creature, tear the uterus, and the more it grows the more it scratches and tears, so that when the hour of birth is near seldom is any of the uterus left intact" (Godley 1982). How and Wells (1989) note in their commentary on these lines that "Aristotle without naming $\mathrm{H}$. (Hist. Au. vi. 31.579 a 2 ) rightly styles this story as to the lioness $\lambda \eta \rho \omega \delta 15$; it w a sinvented. he says, to account lor the scarcity of lions. The lioness breeds once a year, and has uswally three cubs. H. fails to explain how under his system the race of lions survives at all."

7. See West (1997, 342-3), where he notes that both "nēši 'lion' and ıěšti 'lioness"” are lound in different versions of the Akkadian epic, "but the sex of the creature in any case matters little."

8. For more on the ways in which Greck soldiers, and Achilles in particular, see their affection for eacls other in terms of similes involving maternal motifs in Homeric epic, sec Duć and Ebbott (2012); see also Shay (1994, 42).

9. Lioness (Room II Productions, 2008). More information on the film can be found at hetp://lionessthefilm.com

10. Bumiller and Shanker (2013). For the ways in which the practice of using Lionesses ivent against policy (and may have played a role in making a change necessary), see, for example, Shinglc (2009, 155-77).

11. Weaving in ancient Greek is also metaphorically associated with poetry and the ant of narrative (as it also is in the English "text," derived from "textile") and with marriagc. See, for example. McNeil (2005, 1-17).

12. On this key verb and its role in the marrative of the Odyssey, see I, evaniouk $(2011,267)$. 
13. In the words of the literary scholar Heilbrun $(2002,108)$, l'enclope is faced "with an as-yet-unwritten story: how a woman may manage her own destiny when she has no plot, no narrative, no tale to guide her."

14. Sce, for example, Monsacré (1984). All the Greek heroes weep in Homeric epic, with the striking exception of Odysseus, who does not shed a single tear in the llind; sce Pache (2000).

15. Interview with Kate Cuttormsen available on htep://www.pbs.org/independentlens/lioness/guttormsen.html

16. For the comnection between memory and trauma, see, for example, Kenny, Bryant, et al. (2009, 1049-1052).

17. For the connection between traumatic memories and storytelling, and further references to the literature on tramatic memories, see Hunt (2010, 118-20, 126). Cf. Slay $(1994,188-93)$.

18. For outbursts of anger as one of the criteria used to diagnose PTSD, see the American Psychiatric Association's Diagnostic and Statistical Manual of Mental Disorders (DSM-V); sce also Shay $(2003,39-40)$.

19. Shootow! Season 1, Fipisode 11, "Battlecry Iracl: Ramadi," (A \& E Television Networks, 2006).

20. On Penclope's diminished importance as a narrator af ter Odysseus' return, see Nieto (2008, 39-62).

\section{Bibliography}

Bumilter, Elisabeth, and Thom Shanker. 2013. "Equality at the Front I.ine: Pentagon ls Seł to Lift Ban on Women in Combat Roles." New Yonk 'fïmes, January 24.

i.) uć, Casey, and Mary Ebbott. 2012. "Mothers-in-Arms: Soldiers" Fmotional Bonds and Homeric Similes." War, Liserume and ilke Arts 24, hatp://wwhjourual.com/24_1/pdr/DueEbbott.pdf

Foster, Benjanim, trans. 2001. The tiprit of Cïlganmesh. New York: Norton.

Codley, Alfted D., trans. 1982. The Persicus Wers. Folmue 2. Cambridge, MA: Harvard University Press.

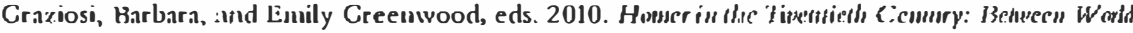
Liecrahure undihe Wessern Canson. Oxford: Oxford University Press.

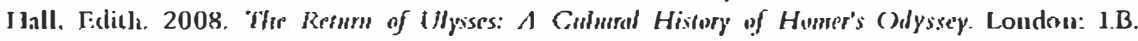
Tauris.

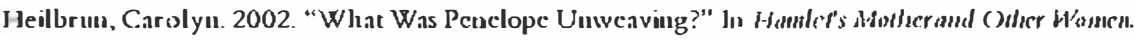
New York: Columbia University Press.

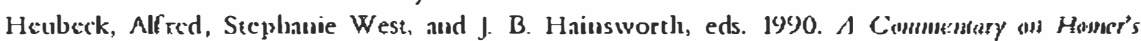

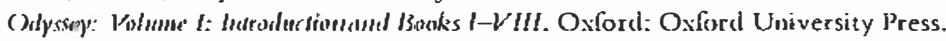

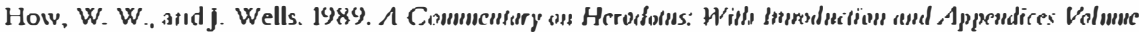

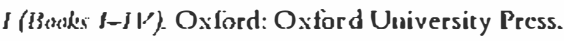

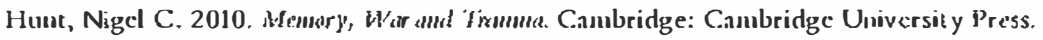

Kenny, L. M., Bryan, R. A., Silove, D., Crcanncr, M., O’Donncll, M., and Alexander C. McFarlane. 2009. "Distan Memories: A Prospective Study of Vantage Point of Tranum Memorics."

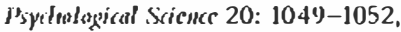

I.attimore, Richmond, traus, 1951. The Hlist of Horser. Clicago, IL: University of Chic ago Press. 1967. T/k' ( Ilyssege' of Homer. New York: Harper and Row.

Magrath, Willian T. 1982. "Progression of the Lion Simile in the "Odyssey', "The Chassicul fonernat 77: 205-12.

Monsacré, Hélène. 1984. Les Larmuss d'Aldilles. Paris: Albiu Miclucl.

Moulton, Carroll. 1977. Similes in the Itomseric Poems. Goetting cul: Vandenhoceck and Ruprecht.

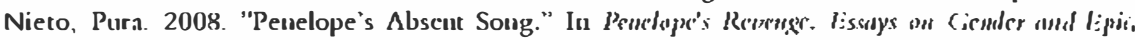
M2octir: 62.1: 39-62. 


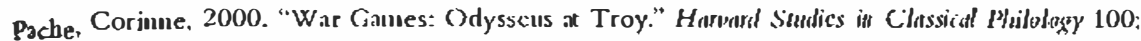
15-23.

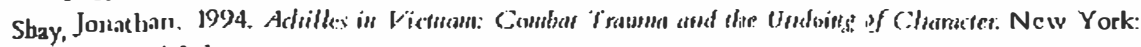
Simon and Schusicr.

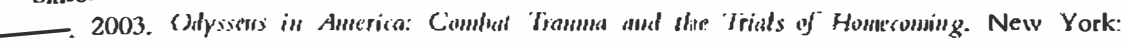
Scribucr.

Sbingle, Jez)nifi:r. 200". "A Disparate lmpact on Femalc Veterans: The Unintended Consequences of Vetcrans AfYairs Regulations Coverning the Eurdens of Proof for Post-Trammatic Stress Disorder Duc to Combat and Military Sexual Tramuta." Millinm \&is Mory Jourmal of Women and flic Lan 16: 155-77.

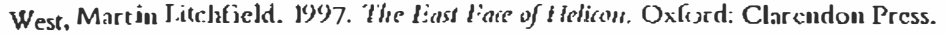

